\title{
Effective Role of Bimstec in the Governance of the Bay of Bengal
}

\author{
Madhumita Kothari, S.Poongavanam
}

\begin{abstract}
The Bay of Bengal Initiative for Multi-Sectoral Technical and financial Cooperation (BIMSTEC) is a local affiliation in south Asia, regarding seven Member States together with India, Bangladesh, Bhutan, Nepal, Sri Lanka, Myanmar and Thailand. These States are within the littoral and close by territories of the Bay of Bengal setting up a coterminous neighborhood cohesion and framing a neighborhood monetary region. The prime Minister of India forced at the combination self-control to bestow crisp strength to BIMSTEC at some stage in its 20thanniversary in 2017. The district however was joined clearly with a rich social legacy yet submit decolonization got impregnated with wrongdoings like rebellion, mental oppression, opiates sneaking, dealing, illegal relocation which provoked the component states to preserve in thoughts inward and fringe safety troubles on want inner characterised wards. The territories of collaboration indoors BIMSTEC that may cover Bay management can also contain change, technology, delivery and communication, Tourism, Fisheries, and surroundings \& weather trade. BIMSTEC pioneers stressed the importance of blue economic system and consented to participate on this phase for low in price development of the vicinity. They selected to build up an Inter-administrative expert organisation to accumulate an hobby plan on blue financial device, remembering the excellent wishes and situations of the landlocked Member States. The BIMSTEC pioneers referred to with fulfillment the facilitating of global Blue economy conference in Bangladesh in 2017 with the cooperation of government agents from BIMSTEC Member States. For India, it's far a characteristic diploma to meet the vital aspect worldwide approach wishes of "network First" and "Act East." The actual circulate outskirt troubles which are influencing the angling business corporation in the Bay amongst others encompass a declining sample in the preferred accessibility of fish; adjustments in species association of gets; the excessive quantity of half of of evolved fish inside the seize; and adjustments in marine biodiversity, mainly through lack of defenseless and jeopardized species. Angling covers national purviews, both legitimately and wrongfully. This has been a sticky problem amongst India and Bangladesh and a extremely increasingly more maximum crucial problem amongst India and Sri Lanka. The real skip fringe problems figuring out with residing regions relate to the misfortune and debasement of mangroves, coral reefs and the lack of, and damage to, ocean grasses. Environmental trade outcomes are shared through all BIMSTEC thing international locations. Exclusive problems of fear within the Bay monetary device relate to nourishment security goals of the seashore terrible, absence of seaside the front development plans, expanding exchange items from waterfront herbal environment, beach advancement and industrialization, ineffectual marine ensured regions and lack of implementation, upstream improvement that impacts waterstream, escalated upstream horticultural practices, and increasing especially appointed the journey enterprise. Infection of the Bay is an immoderate trouble. Aside from industrial
\end{abstract}

business enterprise problems there are crimes that are continuing over the Bay. Consequently, it has was even more super for the BIMSTEC to draft a approach of legitimate collaboration some of the detail states for better management of the Bay with the purpose that a manageable Blue monetary gadget can create and construct the GDP of element states complex. The BIMSTEC wishes to growth its viability inside the route of a advanced administration of the Bay.

Key Words: BIMSTEC, Economic zone, Jurisdiction, Governance, Pollution \& Neighborhood

\section{INTRODUCTION}

The Bay of Bengal ( Bay) is located within the northeastern piece of the Indian Ocean. It's miles certain through arrive on three sides, on the west and northwest by using the usage of India at the north by Bangladesh, and on the east by means of the usage of Myanmar and the Andaman \&Nicobar Islands of India. Its southern cutoff is a line amongst Sri Lanka and the northwesternmost purpose of Sumatra (Indonesia).Critical ports at the Bay contain Paradip, Kolkata, Haldia, Chennai, Visakhapatnam, Kakinada, Pondicherry, Dhamra, Gopalpur in India and Chittagong, Mongla, Payra Ports in Bangladesh. This newsletter investigations the approaching problems in the Bay and the compelling activity that BIMSTEC need to play inside the management of the Bay to decorate the commercial enterprise practicality of the Bay economic area, limit crimes and bolster the development of a possible Blue financial gadget inside the locale. BIMSTEC is moreover an attractive degree for India to show its global approach as 'Act East' and 'community First'. A territorial lawful collaboration to position into effect the provincial desires of harmony in first rate variety alongside those strains is a want.

\section{BIMSTEC}

The Bay of Bengal Initiative for Multi-Sectoral Technical and monetary Cooperation (BIMSTEC) is a local affiliation in south Asia, concerning seven Member States which incorporates India, Bangladesh, Bhutan, Nepal, Sri Lanka, Myanmar and Thailand. The ones States are within the littoral and adjacent zones of the Bay of Bengal comprising an adjoining provincial cohesion and framing a territorial monetary area. The affiliation seemed on 6 June 1997 through the Bangkok assertion.
Revised Manuscript Received on April 12, 2019. India.

Madhumita Kothari, AMET Business School, Chennai, Tamilnadu, India.

S.Poongavanam , AMET Business School, Chennai, Tamilnadu, 
On this manner Bay of Bengal being essential to the BIMSTEC, management of its waters in the nearby oceans, the selective financial zones (EEZ) and within the areas past country wide ward (ABNJ) ought to be the joint and some responsibilities of BIMSTEC contributors.The prime Minister of India underlined on the aggregate purpose to confer crisp energy to BIMSTEC in the course of its 20thanniversary in 2017.

Considering its basis in 1997, BIMSTEC had a slight pace of advancement for remarkable reasons inclusive of political, financial, social and social. The area however changed into joined in truth with a wealthy social legacy but post decolonization have been given impregnated with violations like riot, fear mongering, opiates pirating, dealing, illegal relocation which provoked the element states to don't forget internal and outskirt safety troubles on want. The development plan were given neglected all the while. The seas have been placed to the backburner. Apart from tending to safety issues, development of the blue economic system of the Bay of Bengal in no way were given the favored push. The ocean delimitation problem between India Bangladesh and Bangladesh Myanmar being settled the oceanic zones at once are obviously set aside inside the Bay of Bengal as a ways as purview. This moreover has characterized the ABNJ which have to now incite the element conditions of BIMSTEC to have laws and an administrative device to at the same time and severally oversee the Bay. The areas of collaboration inner BIMSTEC that may cowl Bay control can also moreover include change, technology, transport and verbal exchange, Tourism, Fisheries, and environment and weather change.

\section{BLUE MONETARY SYSTEM INSIDE BIMSTEC}

BIMSTEC pioneers underscored the importance of blue economy and consented to participate on this vicinity for value-efficient improvement of the district. They selected to set up an Inter-legislative expert organisation to accumulate an interest plan on blue economy, remembering the uncommon desires and conditions of the landlocked Member States. The BIMSTEC pioneers referred to with success the facilitating of worldwide Blue economy conference in Bangladesh in 2017 with the help of government delegates from BIMSTEC Member States.

BIMSTEC pals South and South-East Asia, but further the ecologies of the great Himalayas and the Bay of Bengal. With shared qualities, chronicles, life, and predeterminations which are interlinked, BIMSTEC speaks to a regular space for harmony and development. For India, it is a characteristic level to meet the vital factor worldwide method wishes of "community First" and "Act East."

\section{GOVERNANCE OF THE BAY}

Notwithstanding the reality that the Bay has been an inherent piece of the economy of the BIMSTEC nations, Ocean administration has been a low need hassle for the thing states. No matter whether or not it's miles sovereign locale in the close by waters or privileges of energy within the EEZ or up to now as that is involved management of $\mathrm{ABNJ}$, the legal guidelines are quite restricted and barely in form with not unusual global valid machine. The general public of these component states have out of date frontier criminal suggestions as but administering the waters of the locale. The nonappearance of legal guidelines has made massive open doorways for the criminal additives to vitiate the concord and lawful request inside the waters bringing approximately profoundly settled in horrible change practices overwhelmed through unlawful impacts over. The maximum endorsed organization is angling inside the area portrayed via over abuse of reachable catch.

The Bay of Bengal has 475 precise sorts of fish and 36 forms of shrimps, within the 2017-18 monetary year, 6.Five lakh ton of fish was introduced from the Bay which is in greater of seven percentage of the arena's trap .The actual move fringe issues which are influencing the angling enterprise within the Bay amongst others contain a declining pattern inside the full-size accessibility of fish; adjustments in species advent of gets; the high quantity of half of grownfish in the seize; and modifications in marine biodiversity, especially via loss of defenseless and imperiled species. Angling covers countrywide locales, every legitimately and unlawfully. This has been a sticky problem amongst India and Bangladesh and a slightly step by step major difficulty amongst India and Sri Lanka.International places are encountering problems in actualizing fisheries the executives, specifically the natural machine manner to address fisheries.

Cove of Bengal countries contribute basically to the global problem of lack of defenseless and jeopardized species and there can be absence of execution of appropriate techniques at state level. There is open get admission to to angling grounds. The administrations of those encompassing nations pressure on increasing fish gets due to excessive client interest for fish. There may be unseemly government endowments given to fishers. Further, growing angling exertion, especially from trawlers and tote seiners together with for seed and fishmeal for aquaculture, inadequate fisheries the executives, illicit and ruinous angling similarly add to the hardships of the angling industrial agency of the place. That is the place BIMSTEC desires to guide the \%. In viable control for a viable development of the angling commercial enterprise as an quintessential piece of the blue monetary machine. Valid participation among part states to assume on settling the ones problems is an outright need.

The Bay of Bengal is a territory of excessive biodiversity, with many jeopardized and helpless species. The actual move outskirt troubles identifying with territories relate to the misfortune and corruption of mangroves, coral reefs and the lack of, and harm to, ocean grasses. Environmental trade effects are shared with the useful resource of all BIMSTEC detail states. Terrific issues of worry inside the Bay economy relate to nourishment protection desires of the seashore the the front negative, absence of seaside improvement plans, expanding trade items from waterfront dwelling areas, beach front development and industrialization, inadequate marine ensured regions and shortage of requirement, upstream improvement that affects water-waft,in depth upstream horticultural practices, and 
increasing impromptu the journey enterprise. In the event that those troubles aren't characterized and overseen effectively with a right technique and an administrative component, those will begin eating into the financial system in place of coming approximately in developmen $\mathrm{t}$.

\section{POLLUTION OF THE BAY \& RESULTS}

Contamination of the Bay is an immoderate hassle. Release of untreated/in element treated sewage,sewage and herbal releases from the Ganges-Brahmaputra-Meghna River, Sewage-borne pathogens and herbal burden, robust waste/marine muddle, growing supplement inputs, oil contamination, diligent herbal poisons (POPs) and constant deadly materials (PTSs), sedimentation, and overwhelming metals are wrecking the surroundings of the Bay. Plastics and forsaken angling rigging may be moved lengthy separations crosswise over seas. Contrasts among nations with appreciate to guideline and implementation of transportation releases may also power releases over the seas. Tar balls are shipped lengthy separations. POPs/PTSs and mercury, which encompass organo-mercury, enjoy prolonged-pass transportation. Sedimentation and maximum substantial metal tainting will in desired contaminate regionally. Increasing seashore the front populace thickness and urbanization, better utilization, bringing about progressively waste produced consistent with character, missing property dispensed to squander the executives, movement of enterprise and multiplication of little corporations are linked problems of real duration that require sway evaluation and tenet.

Apart from business organization issues there are crimes that are enduring over the Bay. Psychological battle, Smuggling of medications, human dealing, pirating of stash matters are a completely normal thing over the Bay. IUU Fishing within the EEZ of different element states has been a reason for stress between detail conditions of the BIMSTEC.

\section{CONCLUSION}

Problems inside the sound are each verifiable and due to later global upgrades. Along these lines, it has was even greater massive for the BIMSTEC to draft a approach of legitimate collaboration most of the factor states for higher management of the Bay with the purpose that a cheap Blue financial machine can create and construct the GDP of detail states complex. The brotherly love in various variety that is a absolutely unique feature of the BIMSTEC worldwide locations can genuinely fructify simply at the same time as there may be concord and safety in the vicinity. Along those traces BIMSTEC is relied upon to expect an imperative activity in administration of the Bay and India wishes to assume a role of authority to offer impact to its 'neighborhood First' and 'Act East policy' and ingest the development stun of the entrance of Belt and street Initiative of China by means of using a more grounded and extra advanced BIMSTEC with an progressed management of the Bay financial zone.

\section{REFERENCES:}

1. http://www.theindependentbd.com/post/164415

2. Indian Ministry of External Affairs, "Prime Minister's Message on 20th Anniversary of Establishment of BIMSTEC," June 6, 2017, http://www.mea.gov.in/SpeechesStatements.htm?dtl/28514/Prime_Ministers_message_on_20t h_anniversary_of_establishment_of_BIMSTEC

3. http://www.worldbank.org/en/news/infographic/2017/06/06/bl ue-economy

4. http://thecommonwealth.org/blue-economy

5. https://www.undp.org/content/undp/en/home/blog/2018/blueeconomy-sustainable-ocean-economic-paradigm.html

6. https://www.iucn.org/theme/marine-and-polar/ourwork/international-ocean-governance

7. https://thediplomat.com/2018/11/can-bimstec-finallybecome-relevant/

8. https://thediplomat.com/2018/08/making-sense-of-indiasrevived-interests-in-bimstec/

9. https://www.hindustantimes.com/india-news/what-is-bimstecand-why-is-it-important-for-india/story-

SPT8asnufTPmW1kxG5PLaP.html

10. Rajasekar D (2017). A study on motivation level of employees in automobile industry, International journal of Mechanical engineering and technology, 8(12), pp744- 749.

11. Rengamani.J, A Study On The Marine Engineers Retention Strategy by The Shipping Companies In India, International Journal of Production Technology and Management (IJPTM), 9(2), 2018, pp. 23-30.

12. Rengamani.J, Impact of Goods and Services Tax (GST) on the Shipping Companies in Chennai Sector, International Journal of Mechanical Engineering and Technology, 9(8), 2018, pp. 827-835.

13. Thiruvasagam, G., \& Rajasekar, D. (2017). Customer options in wealth management with reference to mutual funds, chennai. International Journal of Economic Research, 14(4), 345-352.

14. Vettriselvan R., Sathya M., \& Velmurugan T. (2018), Productivity and Profitability Mechanical Engineering Entrepreneurs: Business Perspective, International Journal of Mechanical Engineering and Technology, 9(8): 758-765.

15. Vettriselvan R., \& Ruben Anto., (2018) Pathetic Health Status and Working Condition of Zambian Women, Indian Journal of Public Health Research \& Development, 9(9):259-264.

16. Vettriselvan, R., Antony Jesu Rajan, F. S. A., \& Arunkumar, N. (2019). Occupational health issues faced by women in spinners. Indian Journal of Public Health Research and Development, 10(1), 500-504.

\section{AUTHORS PROFILE}

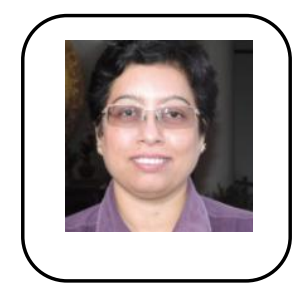

Madhumita Kothari is a Research Scholar in Maritime Studies at AMET Business School, AMET University Chennai. She is an International lawyer, a practicing Advocate \& Managing Partner of Juris International. She is an LL.M. with distinction from UK in Shipping Laws and a PGD gold medalist in International Laws. Besides she also has her Masters in Management \& Geography. She has studied Law in India, Germany and United Kingdom with specialization in International Commercial Arbitration and Shipping Laws. She is a keynote speaker in various international conferences and she has been presenting 
various conference papers in her areas of expertise globally. She has received various national \& international awards like Bharat Gaurav Ratna (Pride of India) award for excellence in Maritime Studies, International Women Achiever's Award and Kala Samman Award as a legal luminary. Some of her notable publications include Rule of Law \& Belt \& Road Initiative, Enforcement of International Arbitral Awards \& Public Policy in India, Legal Cooperation within BIMSTEC \& BRI Connectivity. Her important international conference papers include: India, a cost effective destination for International Commercial Arbitrations: paper presented at the conference of International Council of Jurists, in London, presided over by the President International Court of Justice, HE Mr. Peter Tomka, June 2014, Enforcement of Arbitration Awards in India: paper presented at the conference of the International Council of Jurists in New Delhi, India in 2013, Need for a Better Human Rights Management in Asia: paper presented on the occasion of UN @70 an international conference at Amity University, Noida India 2017, Dispute Resolution under Law of the Sea Convention 1982: Gujarat National Law University Sep 2018, Role of Port State Control in elimination of substandard shipping: Gujarat National Law University Sep 2018, The necessity of General Average in Shipping : Gujarat National Law University Sep 2018, Increasing effectiveness of Port State Control to eliminate substandard Shipping : Central University of Gujarat Feb 2019, Rule of Law in the backdrop of BRI Connectivities : Central University of Gujarat March 2019, Rule of Law and BRI : CCAS Conference in IIC April 2019.

Dr.S.Poongavanam working as a Professor in AMET Business School, Academy of Maritime Education and Training (AMET) Deemed to be University. He done his Doctorate degree in Bharathidasan University. So far he has published nearly 127 articles in Scopus indexed/UGC approved journals and other indexed journals. He participated and presented 25 papers in international conference/seminar. He got five awards from reputed institutions. $\mathrm{He}$ is member of editorial board in seven international journals. 